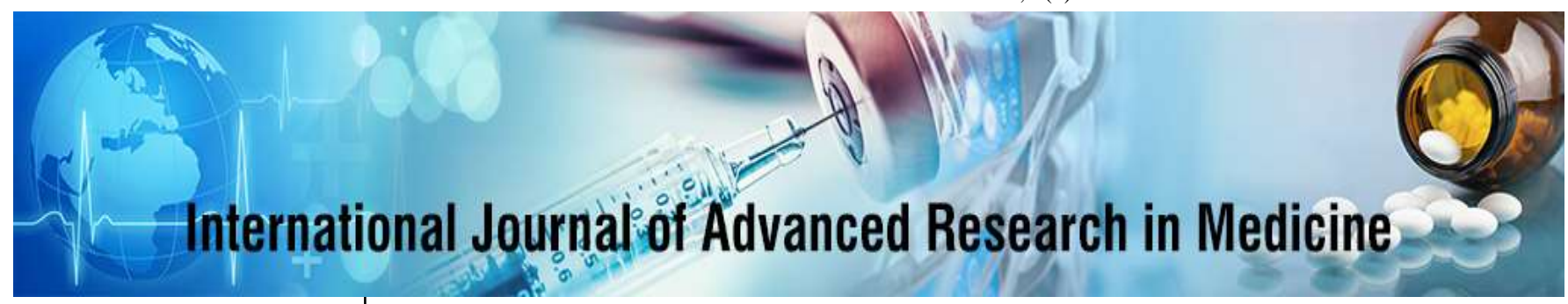

E-ISSN: 2706-9575

P-ISSN: 2706-9567

IJARM 2021; 3(1): 344-347

Received: 16-02-2021

Accepted: 20-03-2021

\section{Dr. Leela GR}

Associate Professor,

Department of OBG,

Kannur Medical College,

Anjarakandy, Kannur, Kerala, India

\section{Dr. Pandurangaiah R}

Associate Professor,

Department of OBG,

Kannur Medical College,

Anjarakandy, Kannur, Kerala, India

\section{Dr. Gopeenath $\mathbf{P}$}

Senior Resident, Department

of OBG, Kannur Medical

College, Anjarakandy,

Kannur, Kerala, India

\section{Dr. Shivaraj BM}

Assistant Professor,

Department of PSM,

Chikkamangaluru Institute

Medical Science,

Chikkamagalur, Karnataka, India
Corresponding Author:

Dr. Pandurangaiah R

Associate Professor,

Department of OBG,

Kannur Medical College,

Anjarakandy, Kannur, Kerala, India

\section{Knowledge, attitude and practice toward COVID-19 among students after reopening of college: a cross- sectional analysis}

\author{
Dr. Leela GR, Dr. Pandurangaiah R, Dr. Gopeenath P and Dr. Shivaraj \\ BM
}

DOI: https://doi.org/10.22271/27069567.2021.v3.i1f.163

\begin{abstract}
Background: After schools, colleges and university campuses opened after 290days of restrictions and lockdown imposed in the wake of the COVID-19 pandemic in Kerala colleges opened from Jan 2021.its necessary to understand about the corona disease and it's also essential for controlling the spread of disease knowing students' knowledge, attitude, and practices (KAP) towards COVID-19.

Materials and Methods: It's a cross-section study done on students after reopening of colleges and online Google questions regarding the KAP of the population about COVID-19 was asked, and participants' demographic characteristics and source of information regarding COVID-19 were recorded and analysed.

Results: We studied 1000 students after college reopening, majority are in age group $20-23 \mathrm{yrs}, 85 \%$ as adequate knowledge, 64 had positive attitude and $80 \%$ are with safety practices.

$95.4 \%$ student's knows the spread, signs and symptoms, risk factors, co-morbidity of disease,

That have slight negative attitude as more than half $51 \%$ as history of group gathering after college reopens $70 \%$ Good practices of COVID protective measures $98.7 \%$ using N95 mask.

Conclusions: Majority of students as good knowledge, positive attitude, and good practice. Suggested for online theory classes and small group practical classes, hostel restriction's for better health of students in college.
\end{abstract}

Keywords: Attitude, COVID-19, knowledge, practice, college students

\section{Introduction}

At the end of 2019 world faces a new challenge to overcome the new viral disease, The novel Coronavirus officially called as COVID-19, it is 1st identified in the city of Wuhan in China ${ }^{[1]}$. Later its spreads to all the nations' world-wide including india, World health organisation on 12th March 2020 decleared it as an global pandemic ${ }^{[2]}$.

COVID-19 is a coronavirus family similler to SARS faced in Asia and MERS in Middle Eastcountry. Its gaining infectivity speed with each mutation as incubation of 2 weeks ${ }^{[3]}$, and mortality range up to 7 weeks ${ }^{[4]}$. India as 2 nd largest population in Asia and faces high no of case in each waves of attack measures are to be taken to spread of the infection.

The most common symptoms of COVID-19 are

- Fever

- Dry cough

- Fatigue

Others less common includes

- Loss of taste or smell,

- Nasal congestion,

- Conjunctivitis (also known as red eyes)

- Sore throat,

- Headache,

- Muscle or joint pain,

- Different types of skin rash,

- Nausea or vomiting, 
- Diarrhoea,

- Chills or dizziness.

People aged 60 years and over, and those with underlying medical problems like high blood pressure, heart and lung problems, diabetes, obesity or cancer, are at higher risk of developing serious illness.

COVID-19 is spread by dust particles and fomites while close unsafe touch between the infector and the infected individual. Airborne distribution has not been recorded for COVID-19 till today there is no treatment to come back infection only 2 vaccines available in India are Covishield and Covaxin. spread of infection as to be prevented by simple measures Stay safe by taking some simple precautions, such as physical distancing, wearing a mask, especially when distancing cannot be maintained, keeping rooms well ventilated, avoiding crowds and close contact, regularly cleaning your hands, and coughing into a bent elbow or tissue ${ }^{[5,6]}$.

After schools, colleges and university campuses opened after 290days of restrictions and lockdown imposed in the wake of the COVID-19 pandemic in Kerala colleges opened from Jan 2021.its necessary to understand about the corona disease.

Certain behavioural and life style changes by authorities and educating people regarding the knowledge, attitudes, and practices (KAP) toward COVID-19 plays important role ${ }^{[7]}$.

\section{Aims and objectives}

The objective of the study is to assess the knowledge, attitudes and practices toward COVID-19 among students after reopening of college.

\section{Material and Methods}

This is a cross-sectional survey was conducted from $01^{\text {st }} \mathrm{Jan}$ to march 2021,during unlock phase of the nation data collected through online Google questionnaire, ethics committee approval was not taken as it's an basic KAP study after consent socio-demographic and KAP questions allow to answer, KAP developed as guidelines given by WHO And data are tabulate and analysis done by using (SPSS) version 24.0 on frequencies, mean, median, percentages, standard deviation and Chi-square test are used to get results.

\section{The inclusion criteria}

- Age group more than 20 years

- $\quad$ filled all the questions

- Residents of India

\section{Exclusion criteria}

- Not willing to participate

- Incomplete answering

\section{Results}

We studied a group of 1000 students after the college reopen among them large number of study students in 20 $23 y r s$, more of females(550), more are less equal number in each religion, $61.2 \%$ are from rural area, living in joint family $(54.3 \%)$ and $61 \%$ are unmarried.
Coming to study proper of knowledge of COVID-19, 95.4\% student's know that its mainly infect from the infected person, they know main symptoms and signs like fever $(92.4 \%)$, dry cough $(96.6 \%)$, breathlessness $(85.7 \%)$ even after this $1.3 \%$ of students don't know symptoms. $60.30 \%$ of students aware that it will spread from both persons who is having signs and symptoms and without any symptoms, about severity of disease $70.10 \%$ infection is not dangers for life in all infected person and $85.60 \%$ of students know the comorbid conditions whom infection is dangers including pregnancy $(72.10 \%), 92.9 \%$ knows India is one of the country to produce COVID 19 vaccine in 2types $n$ its effective to COVID19 infection prevention, certain measures like hand washing $(82.4 \%)$ with soap, mask and avoiding crowed area will prevent disease, $91.10 \%$ will go with quarantine and isolation can prevent spread, maintain 2 feet distance away can prevent spread, But eating non veg can spread only go with $8.80 \%$ and eating habits of vitamin$\mathrm{c}$ rich food will boost the immune response $(42.1 \%)$ habits like alcohol consumption prevents infection in $68.9 \%$ lastly from pet animals $72.5 \%$ tells it won't spread from it.

Our study group attitude towards COVID-19 shown in table 3 , more than half $(51 \%)$ of the people are involved in closed gathering like birthday party, functions after relaxing lockdown, not have any hope that we can prevent infection effectively in India, our students are opposing of lockdown (70\%) to prevent spread of infection.

Table 4 will give their practices in COVID era, maximum number of students are all following the protective measures even after unlock of lockdown and opening colleges like wearing N95mask, frequent hand washing, avoiding unnecessary visiting public places.48.7\% only agrees with govt ideas of medicine stocking. Experiencing happy family time and bounding with family members in lockdown $(85.4 \%) .44 .7 \%$ of students are changing mask every day.

Table 1: Demographic data of the college students groups

\begin{tabular}{|c|c|}
\hline Age group (years) & Number $(\%)$ \\
\hline $20-23$ & $654(65.4)$ \\
\hline $24-26$ & $188(18.8)$ \\
\hline $27-30$ & $93(9.3)$ \\
\hline $31-33$ & $54(5.4)$ \\
\hline$\geq 34$ & $11(1.1)$ \\
\hline \multicolumn{2}{|l|}{ Gender } \\
\hline Male & $450(45)$ \\
\hline Female & $550(55)$ \\
\hline \multicolumn{2}{|l|}{ Religion } \\
\hline Hinduism & $34(134.1)$ \\
\hline Christianity & $324(32.4)$ \\
\hline Muslim & $301(30.1)$ \\
\hline Others & $34((3.4)$ \\
\hline \multicolumn{2}{|l|}{ Marital status } \\
\hline Unmarried & $610(61)$ \\
\hline Married & $390(39)$ \\
\hline \multicolumn{2}{|l|}{ Type of family } \\
\hline Nuclear & $457(45.7)$ \\
\hline Joint & $543(54.3)$ \\
\hline \multicolumn{2}{|l|}{ place of residence } \\
\hline Urban & $388(38.8)$ \\
\hline Rural & $612(61.2)$ \\
\hline
\end{tabular}


Table 2: COVID-19 disease: Knowledge among college students.

\begin{tabular}{|c|c|c|c|c|}
\hline & Knowledge & No. & $\%$ & \\
\hline \multirow[t]{7}{*}{ K1 } & How does infection spread? & & & \\
\hline & Close Contact with diseased person & 954 & 95.4 & \\
\hline & Sneezing & 662 & 66.2 & \\
\hline & Coughing & 789 & 78.9 & \\
\hline & Sharing things & 685 & 68.5 & \\
\hline & Through food & 45 & 4.5 & \\
\hline & Don't know & 11 & 1.1 & \\
\hline \multirow[t]{11}{*}{$\mathrm{K} 2$} & COVID-19 features & & & \\
\hline & Breathlessness & 857 & 85.7 & \\
\hline & Fever & 924 & 92.4 & \\
\hline & Dry Cough & 966 & 96.6 & \\
\hline & Throat pain & 442 & 44.2 & \\
\hline & Watery discharge form nose & 662 & 66.2 & \\
\hline & Generalized weakness & 423 & 42.3 & \\
\hline & Muscle pain & 748 & 74.8 & \\
\hline & Don't know & 13 & 1.3 & \\
\hline & & Yes & No & \multirow{2}{*}{$\begin{array}{l}\text { Don't know } \\
\text { No. }(\%)\end{array}$} \\
\hline & & No. (\%) & No. (\%) & \\
\hline K3 & All infected persons will spread irrespective of its symptoms & $\begin{array}{c}603 \\
60.30 \%\end{array}$ & $\begin{array}{c}300 \\
30.00 \%\end{array}$ & $\begin{array}{c}97 \\
9.70 \%\end{array}$ \\
\hline K4 & COVID-19 infected persons life is danger & $\begin{array}{l}287 \\
28.70 \%\end{array}$ & 701 & $120 \%$ \\
\hline K5 & $\begin{array}{c}\text { Disease is danger in comorbid conditions like high blood pressure, diabeties, asthma, } \\
\text { cancer patient }\end{array}$ & $\begin{array}{c}856 \\
85.60 \%\end{array}$ & $\begin{array}{c}140 \\
14.00 \%\end{array}$ & $\begin{array}{c}4 \\
0.40 \%\end{array}$ \\
\hline K6 & Pregnant patients are come in danger category & $\begin{array}{c}721 \\
72.10 \%\end{array}$ & $\begin{array}{c}125 \\
12.50 \%\end{array}$ & $\begin{array}{c}154 \\
15.40 \%\end{array}$ \\
\hline K7 & COVID -19 vaccines and availability, production and effective ness of Indian vaccines. & 12 & $\begin{array}{c}929 \\
92.90 \%\end{array}$ & $\begin{array}{c}59 \\
5.90 \%\end{array}$ \\
\hline K8 & Protective measures - hand washing with soap, face mask. & $\begin{array}{c}824 \\
82.40 \% \\
\end{array}$ & $\begin{array}{c}124 \\
12.40 \% \\
\end{array}$ & $\begin{array}{c}52 \\
5.20 \% \\
\end{array}$ \\
\hline K9 & Contact tracing and quarantining them is important to prevent spread? & $\begin{array}{c}911 \\
91.10 \%\end{array}$ & $\begin{array}{c}78 \\
7.80 \%\end{array}$ & $\begin{array}{c}11 \\
1.10 \%\end{array}$ \\
\hline K10 & Maintaining 2 feet distance will prevent spread of infection & $\begin{array}{c}945 \\
94.50 \%\end{array}$ & $\begin{array}{c}52 \\
5.20 \%\end{array}$ & $\begin{array}{c}3 \\
0.30 \%\end{array}$ \\
\hline K11 & Infection spread with non-veg food & $\begin{array}{c}88 \\
8.80 \%\end{array}$ & $\begin{array}{c}589 \\
58.90 \%\end{array}$ & $\begin{array}{c}323 \\
32.30 \%\end{array}$ \\
\hline K12 & Eating food rich in vitamin-c increases immunity? & $\begin{array}{c}421 \\
42.10 \% \\
\end{array}$ & $\begin{array}{c}384 \\
38.40 \% \\
\end{array}$ & $\begin{array}{c}195 \\
19.50 \% \\
\end{array}$ \\
\hline K13 & Habit of alcohol drinking are safe from infection & $\begin{array}{c}689 \\
68.90 \%\end{array}$ & $\begin{array}{c}121 \\
12.10 \%\end{array}$ & $\begin{array}{c}190 \\
19.00 \%\end{array}$ \\
\hline K14 & Pet animals spread infection & $\begin{array}{c}78 \\
7.80 \%\end{array}$ & $\begin{array}{c}725 \\
72.50 \%\end{array}$ & $\begin{array}{c}197 \\
19.70 \%\end{array}$ \\
\hline
\end{tabular}

Table 3: COVID-19: disease Attitude among college students.

\begin{tabular}{|c|c|c|c|}
\hline & \multirow{2}{*}{ Attitude } & Yes & No \\
\hline & & No. $(\%)$ & No. $(\%)$ \\
\hline A1 & Any recent events of Group gathering like birthday party, marriage, religious functions, market, malls & $\begin{array}{c}489 \\
49 \%\end{array}$ & $\begin{array}{c}511 \\
51 \%\end{array}$ \\
\hline A2 & India can able to control infection of COVID-19 and its morbidity. & $\begin{array}{l}300 \\
30 \%\end{array}$ & $\begin{array}{l}700 \\
70 \%\end{array}$ \\
\hline A3 & Complete lockdown in country will prevent people contact and spread of infection & $\begin{array}{c}296 \\
30 \% \\
\end{array}$ & $\begin{array}{l}704 \\
70 \% \\
\end{array}$ \\
\hline
\end{tabular}

Table 4: COVID-19 disease: Practices among college students.

\begin{tabular}{|c|c|c|c|}
\hline & Practices & No. & \% \\
\hline P1 & What kind of preventive measures you take while leaving home? & & $98.7 \%$ \\
\hline & Wear N95 mask & 987 & $42 \%$ \\
\hline & Distancing of 2 feet from each other & 420 & $48.9 \%$ \\
\hline & Frequent washing hands with soap & 489 & $98.5 \%$ \\
\hline & Avoid Greeting by touching & 985 & $78.9 \%$ \\
\hline & Avoid visiting public place & 789 & $45.7 \%$ \\
\hline & Self-quarantine on contacts with infected person & 457 & $1 \%$ \\
\hline & None & Yes No. (\%) & No. No(\%) \\
\hline P2 & Do you go with govt rules of medicines stocking & 487 & 513 \\
\hline
\end{tabular}




\begin{tabular}{|c|c|c|c|}
\hline & & $48.7 \%$ & $51 . \%$ \\
\hline \multirow{2}{*}{ P3 } & Lockdown gave time to spend with family and bounding & 854 & 146 \\
& & $85.4 \%$ & $14 \%$ \\
\hline \multirow{2}{*}{ P4 } & Changing of mask everyday & 447 & 553 \\
\end{tabular}

\section{Discussions}

Corona vires after invading the human race at end of 2019 causing economy variations of countries like India ${ }^{[8]}$ in India now $2^{\text {nd }}$ wave as rampant and in phase of community transmission. We are aim to mental preparedness to the reopened college students regarding KAP of COVID-19.

We found that $85 \%$ had adequate knowledge lesser than zhong et al. in china study $(90 \%){ }^{[9]}$ And higher than study by clementa et al. $(80 \%)^{[10]}$.

Majority of students as good information of spread through contact with diseased person $(95.4 \%)$ which is similar to other studies done on public early days by azlan ${ }^{[11]}$ students aware of signs and symptoms of COVID-19 same findings in azlanand tomar studies ${ }^{[11,12]}$.

Students know the spread of disease in persons without symptoms they know that lives of all infected persons are not in dander only those with comorbid conditions are high risk of dander. Severity will be reduced in vaccinated patient they also know types of vaccine's available in India Well aware of preventive measures like hand washing with soap, N95mask, 2feet distancing, contact tracing and quarantining.

Some misunderstandings about non-veg food consumptions spread from pets and alcohol drinking prevents spread.

In $2^{\text {nd }}$ wave after reopen students lost hopes of winning in India as so many mutations are present in cases $70 \%$ of people have negative attitude in winning.

Students in unlock of lockdown have several incident of attaining group gathering $51 \%$. Also as positive hope that complete lockdown prevents spreed.in tomar study $96 \%{ }^{[12]}$. Even though more negative attitude in students but more than 90\% using good measures to prevent COVID-19, $98.7 \%$ using N95 mask, avoid greeting by touch, $78 \%$ avoiding public place. In study of rios were masks when going out $74.31 \%$ only which is lesser than our study [13].

\section{Conclusion}

Study students after reopening as adequate information of COVID-19 KAP but due to prolong and restriction students thinking future and life they are having little negative attitude but good safe practice.

Government or college principle should have rules $n$ restriction to the students while running colleges, studies showed that in reopening colleges difficult to have safe practices. Suggested for online theory classes and small group practical classes, hostel restriction's for better health of students in college.

\section{Acknowledgment}

We thank to the management of KMC, Anjarakandy, KMC and faculty, department of OBG.

\section{References}

1. Young Charles. COVID-19: Novel Coronavirus. International Journal of Clinical Practice 2020;74(4):24-25.
2. World Health Organization. WHO announces COVID19 outbreak a pandemic. http://www.euro.who.int/en/health-topics/healthemergencies/coronavirus-COVID-

19/news/news/2020/3/who-announces-COVID-19outbreak-a-pandemic [Accessed 12 March 2020].

3. Wang W, Tang J, Wei F. Updated understanding of the outbreak of 2019 novel coronavirus (2019-nCoV) in Wuhan, China. J Med Virol 2020;92;441-7.

4. Maysoon D, Kevin van Z, Stefan F, Abdihamid W, Paul BS, Ronald W, et al. COVID-19 control in lowincome settings and displaced populations: what can realistically be done? London Sch Hyg Trop Med. 2020;14(1)1-10.

5. Wong G, Liu W, Liu Y, Zhou B, Bi Y, Gao GF. MERS, SARS, and Ebola: The role of super-spreaders in infectious disease. Cell Host Microbe Forum 2015;18(4):398-401

6. Azlan AA, Hamzah MR, Sern TJ, Ayub SH, Mohamad E. Public knowledge, attitudes and practices towards COVID-19: A cross-sectional study in Malaysia. PloS One 2020;15(5):1-1.

7. National Institution for Transforming India. State statistics: population density. [https://www.niti.gov.in/niti/content/populationdensity-sq-km]; 2011 [Accessed August 26, 2020].

8. Zhong BL, Luo W, Li HM, Zhang QQ, Liu XG, Li WT, et al. Knowledge, attitudes, and practices towards COVID-19 among Chinese residentsduring the rapid rise period of the COVID-19 outbreak: A quick online cross-sectional survey. Int J Biol Sci 2020;16:1745-52.

9. Olum R, Chekwech G, Wekha G, Nassozi DR, Bongomin F. Coronavirus disease-2019: Knowledge, attitude, and practices of health care workers at Makerere University Teaching Hospitals, Uganda. Front Public Health 2020;8:181.

10. Azlan AA, Hamzah MR, Sern TJ, Ayub SH, Mohamad E. Public knowledge, attitudes and practices towards COVID-19: A cross-sectional study in Malaysia. PloS One 2020;15(5):1-15.

11. Tomar BS, Singh P, Suman S, Raj P, Nathiya D. Indian community's knowledge, attitude and practice towards COVID-19. Med Rxiv. 2020, 1-20.

12. Rios-González CM. Knowledge, attitudes and practices towards COVID-19 in Paraguayans during outbreaks: a quick online survey. SciELO Prepr 2020, 1-20. Available from: https://preprints.scielo.org/index.php/scielo/preprint/ view/149/179.

13. Rahman A, Sathi NJ. Knowledge, attitude, and preventive practices toward COVID-19 among Bangladeshi internet users. Electron J Gen Med. 2020;17(5):1-6. 